\title{
Nostalgia and Alienation in the Poetry of Arab- American Mahjar Poets (Emigrant Poets): Literary Criticism to Stylistics
}

\author{
Ibrahim Mohammad Abushihab \\ English Department, Faculty of Arts, Al-Zaytoonah University of Jordan, Jordan \\ Enas Sami Awad \\ Al-Zaytoonah University of Jordan, Jordan \\ Esraa Ibrahim Abushihab \\ Yarmouk University, Jordan
}

\begin{abstract}
Nostalgia and Alienation are defined as the feeling that one has when he finds himself alone without connection with the people around him. He considers himself as a stranger in the society where he lives. This is due to leaving the people and homelands. This is what happened to Arab-American poets, (Emigrant poets) who leave their homelands and people. The current paper presents Arab- American poets' longing, deep love, nostalgia and feeling of homesickness for their beloved countries in East. It also shows their adherence and alienation to their homelands by remembering the years and times they lived there. It emphasizes literary criticism of describing, analyzing and evaluating some of Arab- American poems.
\end{abstract}

Index Terms-Mahjar poets, nostalgia, alienation, and literary criticism

\section{INTRODUCTION}

It is not easy for the Arab- American poets (Mahjar poets) to leave the lands of civilization and the oldest cities like Damascus, Beirut and Cairo to find themselves in countries that have a different culture, thought, race, religion, etc. Orfalea and Elmusa (1988) state that "Arab Americans may be more inclined than more to ask the question: Is it right to isolate poetry based on ethnic origin? Descended from people that lived on the crossroads of East and West, their heritage is uniquely international. They know well that poetry is one of the few human means to break through barriers of race, religion, nationality, sex and language." (P.x111) Based on these challenges, they composed the best poems which were grounded on their love and belonging to the East. They composed their poems following a new form of poetry because of their contact with the West and used free verse of composing poetry which helped them express their ideas freely and easily. This is considered as a challenge against the classical Arabic poetry "qasida." Such type of poetry is suitable for them to express their longing, alienation and nostalgia to their ethnic origins freely.

Alienation is defined as the feeling one has when he finds himself alone without knowing anyone around him. Alienation in the ankle of sociology is isolation between one and a group of people in a specific society. As a result, he considers himself as a stranger because of leaving the people and homelands. Al-Issa (2003) identifies the major characteristics of Al- Mahjar poets (emigrant poets). He assures that nostalgia and alienation for their homelands and people are the central theme of their poetry. Mahjar poets focus on their deep love for their countries, their nostalgia of the memories of the past and their alienation for the childhood. Gibran Khalil Gibran (1883-1931) who is one of the Mahjar poets shows his belonging and adherence to the East even though he does not conceal his admiration for the west.

He states:

I shall remain an Easterner

No matter how much I admire Western progress.

Abumadi (1890-1957) remembers his homeland (Lebanon) with bitterness Lebanon is considered to him as the place of stars. In his poem "the baby and the old man", he remarks

$$
\begin{aligned}
& \text { وطن النجوم أنا هنا حذّف اتذكر من أنا } \\
& \text { أنا ذلك الولد الذي دنياه كانت هاهنا } \\
& \text { O, my staring fatherland }
\end{aligned}
$$

Stare at me, do you know who I am

I am the boy who lives here now

Nasib Arida (1887-1946) is a Mhjar Syrian poet. He also shows his homesickness to his beloved country "Syria". In his poem "The Narration of Experiences of Syrian Emigration", he composes the following verse: 


\section{غريب من بلاد الثرق جئت

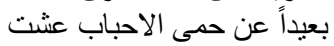

A stranger came from the East

Far away from my beloved homeland I lived

Zaki Qunsul (1916-1994) a Syrian writer remembers his life in his beloved homeland "Syria". He shows his longing in the following verse:

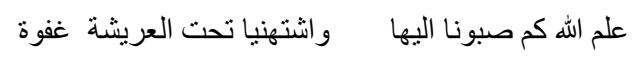

Allah knows how much we love it (Syria).

and we like to take a very short sleep under the pergola.

It is difficult for anyone to leave his homeland and to find himself in a strange county with a different language and culture. This situation gives the person the feeling of homesickness. This is what happens to Mahjar poets (Emigrant poets). In late $1880 \mathrm{~s}$, the political circumstances and socio-economic crisis the Ottoman Empire faced led to large number of people into exile and immigration. A group of writers and poets emigrated to North and South America to avoid political problems. Others emigrated to Australia and Canada. They were exchanging ideas and literary works which led them to form a new kind of Arabic and English literature under the name of Adab al-Mahjor "literature of Diaspora". Gibran Khalil (1883-1931) who was the most important emigrant writer met some other emigrant writers like Rihani (1876-1940); Naimy (1889-1988) and Abumadi (1890-1957) and formed Al-Rabitah Al- Qalamiyah "The pen Association". It was the most prominent literary Association formed by Arab emigrant writers. It played an effective role in the development of modern Arabic literature. The members of the association helped in bridging the gap between the East represented by Arab literature and the West represented by American literature. MecHarck (2006) points out that the pen Association contributed to Arabic literature renaissance. Its members were considered as ambassadors of their homeland to the West. They, in their poems, celebrated the glorious past of the Arab world and were also impressed with values of freedom and democracy and the scientific progress as well in America. The emigrant poets lived as strangers in America because they left their homes and relatives to face and struggle in a country with a new culture and language. They did their best to keep their native language "Arabic". Accordingly, some of them wrote their literary works in English and Arabic as well. They interacted and responded to any cultural and political events that took place in their home countries. They focused on their writing about their feeling and yearning towards their countries and expressed their homesickness towards their beloved countries and people. The most important characteristic of Mahjar poets was nostalgia. They remembered passionately their beloved country they left behind. They tasted the bitter of emigration and found themselves as prisoners in jails in a strange country. They emphasized their adherence, love and belonging to the East.

The emigrant poets are divided into two types:

1. Poets of the North Diaspora: Those who emigrated from the East to the United States of America. Most of them are members of the pen association.

2. Poets of the South Diaspora: Those who immigrated from Syria and Lebanon to South America "Brazil, Argentina, and Mexico" like Fawzi Maalouf (1899-1930); Shafiq al Ma'luf (1905-1977); Mikhail Naimy (1889-1988) and Rashid Salim (1887-1984) among others. They established a literary association called Andalusian League in Brazil in 1933.

Arab-American poems are based on free verse. The poems are free from regular meter or rhythm which is applied in classical poems of the pre-Islamic period. Al-Issa (2003) remarks that the rhythm of Al-Mahjar poems is fixed and there is a variation of rhyme and line length. Morch (1976) adds that Arab- American poets followed the free-verse of writing their poems. They freed themselves from the classical Arabic form which contained a specific number of feet within a verse. The best poems written by Arab- American poets are mostly about longing to their beloved homelands.

\section{HOMESICKNESS AND NOSTALGIA IN ARABIC POETRY}

Love, eagerness, alienation and emigration are found in every age. In pre-Islamic era, people left their homelands searching for water, food or escaping from invasions and raids. The poets at that time showed their alienation to homes, mothers, beloved girls, friends and places. Alienation was the source of inspiration for the pre-Islamic poets to compose the masterpieces of poetry as founded in seven hanging poems "Al-Mu'alqat" which could be the best in Arabic literature. It is said that Hanging Poems "Al-M'alaqat" were called so because they were hanged at the walls of Ka'ba "Muslim sacred place" because of their importance and the best in Pre-Islamic Arabic literature (Ignorant literature). They are considered masterpieces of Arab poetry. Imru' AL-Qais was obliged to leave his relatives and parting love ones. He states the following verse in his masterpiece (al-Mu'laqa):

\section{اجارتنا انا غريبان هاهنا وكل غريب للغريب نسيب \\ O our neighbor, we are strangers here}

And each stranger is a brother for another

The psychological alienation lets the individual feel the absurdity of life and this reflects his behavior represented by his poetry. Turfa Ibn Aal'abd who was a pre-Islamic poet faced oppression of his relatives, so he was an alien and a stranger in his homeland. He expressed his situation in his masterpiece of poetry "AL-Mu'alqa" in Arabic in the following verse: 


$$
\text { وظلم ذوي القربى أشندُ مضاضةٌ على المرء من وقع الحسام المهند }
$$

Oppression and injustice of relatives are more agony and harmful

to a man than the blow of a cutter Indian sword (a sword is made from Indian iron).

Imru' AlQais a Pre-Islamic poet also longs for his beloved "Leyla" and walks by homes of Leila. He finds nothing, but the walls and remains, so he starts kissing them. He composes the following:

$$
\begin{aligned}
& \text { امر على الديار ديار ليلى اقبل ذا الجدار وذا الجدار }
\end{aligned}
$$

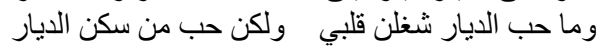

I walk by homes of Leyla. I kiss walls and remains;

It is not the walls and remains which occupy my heart,

but it is the love of the one (Leila) living there;

Bedouins living in the Arabian Desert were animal herders who migrated from place to another seeking for cultivated lands and water especially in the dry summer months. They lived in tents made from goat and sheep hair. Maysoon bint Bahdal was a great poetess who lived in the Arabian Desert. Muawiyah Ibn Abi Sufyan (602A.D-680A.D) the first Umayyad caliph was mesmerized by her beauty and married her in 645 A.D). She left the tent of her family in the desert and moved to a great palace in Damascus which was the capital of the Umayyad caliphate. She felt homesick to her homeland (Arabian desert) and family. She composed a great poem describing her longing to her homeland. The following is some verses of her poem:

$$
\begin{aligned}
& \text { لبيثُ تخفق الارياحُ فيه أحبُّ إليّ من قصرِمنيف } \\
& \text { For a humble tent where winds fall } \\
& \text { is better for me than elevated (lofty) palace } \\
& \text { ولبس عباءةٍ وتقرّ عيني أحبُّ إلىّ من لبس الثفوف } \\
& \text { Wearing a cloak (Bedowin dress) and putting my mind at ease } \\
& \text { is better than wearing soft dress. } \\
& \text { و اكل كُسبرة من كَسرِ بيتي أحبُّ إليّ من أكل الرغيف } \\
& \text { And eating a broken bread from my family } \\
& \text { is better than eating bread (loaf) (metaphorical meaning for delicious food) } \\
& \text { و أصو ات الرياح بكلّ فجّ أحبُّ إليّ من نقر الدفوف } \\
& \text { and the sound of the wind in all directions } \\
& \text { is better than tapping tambourines. } \\
& \text { وكلبُ ينبحُ الطر اق دوني أحبُّ إليّ من قطٌ أليف } \\
& \text { is better than a pet cat. }
\end{aligned}
$$

Ali Ibn Aljahm (803A.D- 863 A.D) was an Abbasid poet who composed the following verses after he was released from the prison and went to cemeteries as a comfortable place.

$$
\text { يشتاق كل غريب عند غربته ويذكر الأهل و الجير ان و الوطن }
$$

When a stranger in alienation, he misses and retains in his memory people, neighbors and homeland,

$$
\text { ليس لي وطن امسيت اذكره الا المقابر اذ كانت لهم وطن }
$$

I have no homeland to remember other than cemeteries which become their homeland.

Ibn AL-Rumi (836A.D-896A.D) was a great poet in Abbasid era. He considered his house as homeland. He addressed his rich neighbor who coveted buying his house. Accordingly, he damaged the walls of Ibn- Al-Rumi's house in order to force him to sell it. Ibn AL-Rumi addressed him in a poem entitled "ولي وطن آليث الا أبيعه" "I have a home I swear not to sell. The following verses are taken from the poem

$$
\text { ولي وطن آليت ألا أبيعه ولا أرى غيري له الدهر مالكا }
$$

I have a home I swear not to sell;

And I do not imagine seeing anyone as its owner;

$$
\text { مآرب قضاها الثبابُ هنالكا وحبّ أوطان الرجال اليهم }
$$

What made the homeland lovely to men;

is the desires and wishes that the youth had there

إذا ذكروا اوطانهم ذكرّتهم عهود الصنّبا فيها فحنو لذلكا

When the men remember their homeland,

the homeland reminded them with boyhood covenants, so they yearn to it.

Qutada Abu-Aziz (1132 A.D-1219A.D) was Amir (prince) of Mecca. He shows his love and loyalty to his family and homeland the following verse:

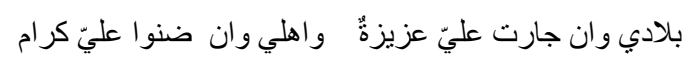

My country is dear to me even if it oppressed and subjugated me and my people are generous even though they make things hard to me

Khairuddin Al-Zirikli (1893A.D-1976A.D) was a Syrian poet who was obliged to leave Syria because of French Mandate for Syria. He showed his homesickness to his homeland (Syria) in a poem entitled The eye العين بعد فر اقها الوطنا The after its separation from homeland". He states the following verses:

$$
\text { العين بعد فر اقها الوطنا لا ساكناً الفت و لا سكنا }
$$


The eye after its separation from homeland;

it is not adopted neither homes nor people there

ليت الذين احبهم علموا وهم هنالك مالقيت هنا

I wish those whom I loved know;

and they are there what I met and suffer here;

Ibn Al-Mu'tazz (861A.D-909 A.D.) was also an Abbasid caliph and a poet who composed a poem about the separation and feeling homesick entitled

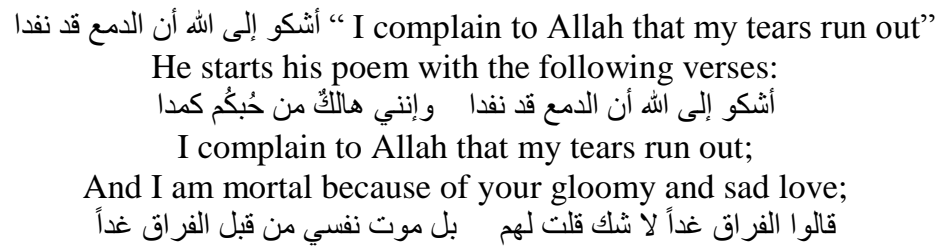

They said the separation will be tomorrow certainly, I informed them that my death will be tomorrow before the moment of separation comes.

Bilal IbnRabah was one of the companions of Mohammad Messenger of Allah (Peace Be Upon Him). He migrated from the oppression of the people of Mecca to Madina. He missed his homeland "Mecca" so much and he remembered the mountains and plants of Mecca. He expresses his homesickness in the following verse:

$$
\text { ألا ليت شعري هل ابيتن ليلة }
$$

I hope to be pleased and happy if I am at the valley (Mecca)

and around me Ithkoruna and Jalilu (nice plants grown in Mecca).

Jamil Ibn Abdullah Al-Udhri (659A.D-701A.D) was considered a love poet in Umayyad caliphate. He was also called Jamil Buthayna after the name of his beloved "Buthayna" who belonged to another tribe. He composed the best poems flirting with her. Accordingly, her father refused to marry her to him and he was threatened by her tribe. This obliged Jamil Buthayna to save his life from death and left his homeland. He longed for his beloved Buthayna and homeland. and he expressed his miserable life in exile as follows:

$$
\text { ألا ليت شعري هل ابيتن ليلة بوادي القرى إني إذا لسعيد }
$$

If only I could be at a'lqira valley (Buthayna's homeland); I hope I will be pleased and happy.

\section{Homesickness AND NostAlgiA IN ARAB-AMERICAN (MAHJAR) POETS}

Most Arab- American poets (Mahjar poets) left their homeland for political and economic reasons to live in one of the youngest countries in the world "America". Their life there was challenging. They lived in a country which had different language, religions, norms, customs, etc., so they had to adapt themselves with such a new life. They were obliged to write poems to express their feelings which were easy to be composed in comparison to writing novels and stories, so they saved their time and efforts. The Mahjar poets like Rihani (1876-1940); Naimy (1889-1988); Abumadi (1890-1957) among others established association, later called Al- Rabitah Al-Qalamiyah "The pen Association". The aim of the Association was to foster intellectual cooperation and understanding among Mahjar poets in America. They wanted to show the importance of literature in world understanding and to preserve and develop Arabic language. Mahjar poets were influenced by the American style of composing poetry. Moreh (1976) states that Mahjar poets followed new forms of poetry because of their contact with Americans. They freed themselves from the classical Arabic form which was formed from a certain number of feet within a verse whereas they used a new form of poetry "free verse". This form helped them to express their feelings and ideas freely and easily. Mahjar poets contributed to the development of modern Arabic poetry. They kept their native language traditions, national ideology and political issues of their countries. Diab (2015) assures that "Rihani was a visionary politician in his call for Arab unity; a reformer in his struggle to develop his homeland, and judicious leader in his appeal for tolerance of opposing cultures, politics and religions" (P.43). Mahjar poets have the freedom to use more than one metre within the same poem and to choose the topic which relate to their life in exile. They were romantics because they were influenced by European romantic literature which was one form of Romantic Movement found in Europe in $19^{\text {th }}$ century. The advocators of this movement were William Wordsworth and Samuel Taylor Coleridge. Accordingly, Mahjar poets altered the verse-form of classical Arabic poetry because they were under the effects of European Romanticism. They wrote about nature, nostalgia and alienation. They also wrote about their bitter feelings of homesickness and their dual cultural life. Khafaji (1986) assures that Mahjar's poets in exile, their worry, sadness and longing to their homelands were expressed in their poems. Mahjar poets like Khalil Gibran among others contributed to Arabic literary renaissance. They revolted against Arabic classical literature. Their alienation to homeland gave them a strong motive and inspiration for composing nostalgic poems. They were flared with the fire of longing to their homelands and they called upon Arabism and patriotism. Their feelings towards their countries were honest and loyal. Elia Abumadi had lived and stayed in Egypt for short time, so he carried his memories to America. He also had a strong feeling towards his birthplace "Lebanon". He composed incredible poems about his homeland "Lebanon" because he considered his life in exile "America" a hell and 
intolerable. If he saw a ship heading from America to Lebanon, this triggered his emotion. He addresses Beirut as follows:

$$
\begin{aligned}
& \text { بيروت يا بنت البحار الجارية فإذا سُئلت من البقايا الباقية }
\end{aligned}
$$

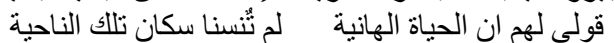

Beirut, the girl of the running seas;

If you are asked about what remains in past;

(Lebanon after the war and colonization), say to them that beautiful and nice life does not make us forget the residents of that place (Beirut).

Abumadi also compared himself with a star because both were strange. He watched the star and asked himself:

$$
\begin{aligned}
& \text { ما لهذا النجم مثلي في الثرى طائرُ النوم شديد الوجل }
\end{aligned}
$$

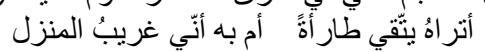

What is this star like me in the earth; it cannot sleep and it is extremely scared;

Does it avoid something urgent or it is like me a stranger in a house.

Abumadi with tears in his eyes because of his longing to his homeland composed a poem under the title "Tears and sighs". He expressed his feeling as follows:

$$
\begin{aligned}
& \text { فأبكي لما بي من جوى وصبابة و أبكي إذا ابصرت في الأرض باكياً }
\end{aligned}
$$

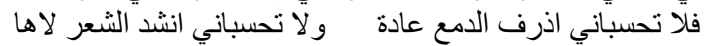

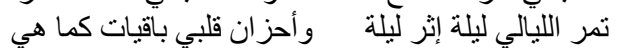

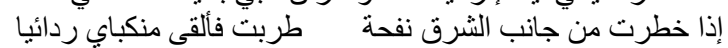

and I cry when I see the earth (reminding him with his homeland);

Don't think that I usually crying.

and don't think that I compose poems for fun;

The nights pass night after night;

and the sorrow of my heart stays as it is;

If gentle breeze comes up from East side;

I am delighted and overjoyed, so my shoulders throw my grown down;

He also describes his isolation and miserable life in exile in a poem entitled "My Neighbor". He describes himself as follows:

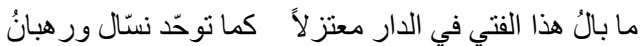

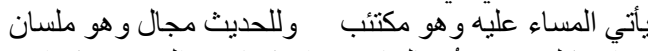

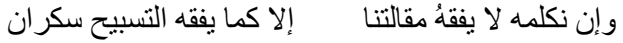

What is wrong with this boy in the house, retired;

As the privacy and loneliness of monks and hermits;

The evening comes upon him and he is depressed and dejected;

And there is a field for talk, but he is silent though he is tactful speaker;

If we speak to him, he understands nothing;

except as the drunk man understands the praise of Allah;

The existential alienation made Elia Abumadi contemplates life and existence, so he finds himself confused and lost. this causes depression and despair to him. In his poem "Riddles" which touches the human thought and existence because of alienation. He concludes in his poem that no one can understand the secret of life:

$$
\begin{aligned}
& \text { جئت لا اعلم من اين وكلني اتيت } \\
& \text { ولقد ابصرت قدامي طريقاً فمشيت التيث }
\end{aligned}
$$

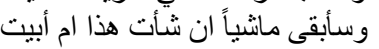

$$
\begin{aligned}
& \text { كيف جئت؟ كيف ابصرت طرياً ان طئي؟ لست ادريت } \\
& \text { I came; } \\
& \text { Not knowing; } \\
& \text { My feet saw the way; } \\
& \text { And I walked there; } \\
& \text { And I shall continue; } \\
& \text { Whether I so desire or not; } \\
& \text { How did I come; } \\
& \text { How see the path? } \\
& \text { I know not; }
\end{aligned}
$$

In his poem "The poet is in the sky, Abumadi wished a summer or a winter in Lebanon because exile spoiled his life;

$$
\text { فقي أرض يارب لبنان أو شتل صيف }
$$




$$
\text { وليس في غربة هناء }
$$

O, Lord I said a summer or a winter in;

Lebanon, I am here (in exile) a stranger;

and there is no felicity and bliss in exile; ( P.74)

Mahjar poets wrote prominent and distinguished poems because of their yearning for nature and their nostalgia to their homelands. They used simple and subtle language. Ameen Rihani (1876-1940) went to New York City in 1888 to pursue his study in English. Karam (2013) assures that Rihani is prominent in modernization and universalism. He was obsessed with fostering social reform. He was also an important political figure. He was obliged to work in restaurants and other low salary jobs for the purpose of earning a living. In his poem "I Dreamed I was a Donkey Boy Again". He liked and longed for the primitive style of life because he suffered in a strange land and people in America. He wrote this poem:

I sit me on a bench and weep; and in my heart, I sing;

O, let me be a burro-boy again;

$\mathrm{O}$, let me sleep among the cyclamens; of my own Land;

(Orfalea and Elmusa,1988)

Jibran Khalil was one the prominent Mahjar poets who was a member of "the Pen Association" and helped in the development of Arabic literature. He expressed his alienation in a poem "Blocked Country". He insisted to leave the country of alienation:

$$
\begin{aligned}
& \text { هو ذا الفجر فقومي ننصرف عن ديار ما لنا فيها صديق }
\end{aligned}
$$

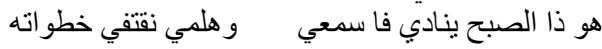

This is the dawn, let us leave;

From homes which we have no friends;

Listen to the call of the morning;

and let us follow its footsteps;

Jibran khalil in the lines stated above made the dawn is the time of departure from the bitterness of exile and loneliness. The dawn is followed by morning which is considered as a human being who calls for the departure of the country where we have no friends. He touches the horizons of self-alienation in a poem entitled 'yesterday':

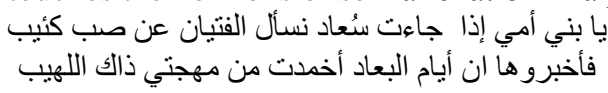

My people, if Suad (imaginary name) comes and asks the young about the severe depression. please tell her that the days of alienation put out the flame from my heart.

Jibran Khalil in his poem "There is no affable and friendship in Exile", complained about the cruelty of the alienation and the miserable life in exile:

$$
\text { في هجره لا أنس فيها للغريب ورلا صفاء }
$$

There is no affable and purity in exile for the stranger

Nimah Alhaj (1896-1978) in a poem initiated by "I remember my family" shows his longing and love to his people and country:

$$
\begin{aligned}
& \text { تذكرت اهلي في النوى وبلاديا وقد طال شوقي للحمى وبعاديا }
\end{aligned}
$$

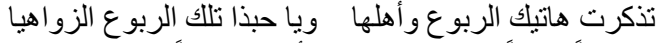

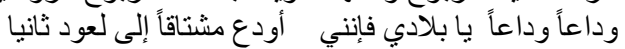

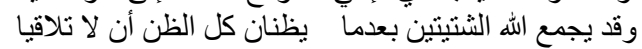

$$
\begin{aligned}
& \text { I remembered my family in exile; } \\
& \text { And I longed for my country in the distance; } \\
& \text { I remembered my country and its people; } \\
& \text { You would like these wonderful countries; } \\
& \text { Goodbye Goodbye my country; } \\
& \text { I say goodbye and I longed for going; } \\
& \text { Back to my country; }
\end{aligned}
$$

Al-Issa (2003) assures that "the sense of estrangement and alienation that accompanied the Arab-American immigrants was further deepened due to the impact of the American metropolis. Most of them came from smaller cities, towns and villages only to face huge high-rise buildings and factories that were scattered across America"( P.42).

Mikhail Naimy (1889-1988) was one of the prominent Mahjar poets who drew a beautiful picture for the future of the immigrants in America. He gave hope and support for them. In his poem "Close your Eyes", he states:

When clouds conceal your skies;

Close your eyes;

And see the stars beyond; 
If earth is wrapped in snow;

Close your eyes;

And see the flowers below;

When sickness knows no ease;

Close your eyes;

And see the cure in the disease;

(Translated by Perry, J.R.,1988)

Edward Said (2003) remarks that the immigrants are those who uprooted from their homelands. Unlike nationalism, exile is considered as a discontinuation state of being immigrants are cut off from their homelands, their land and their past. Accordingly, they suffer from alienation because they are obliged to adapt themselves with a strange culture and people. Hamzah (2016) points out that it is difficult for poets and writers to leave their homelands and to be forced to give up their culture and relinquish their mother tongue. They become absorbed into strange new societies and culture.

\section{CONCLUSION}

Adab aMahjar (Emigrant literature) stands for the Arab emigrant writers who settled in America during the 20th century. They received the support from the Association founded for this purpose. A group of prominent writers like Jibran Khalil Jibran (1883-1931); Mikhail Naimy (1889-11988) and Ameen Rihani (1876-1940) founded an association called "The Pen Association". It revolted the classical Arabic prose and poetry which focused on human emotions and imagination which were reflected in the topics they wrote about like love, criticism, philosophy and nostalgia. Jokandan and Shakib (2015) state that the major characteristics of Mahjar poets in North America were the love of their countries, their tendency to nationalism; their pessimistic outlook towards life and the innovation and introduction of new topics. Mahjar poets focused on their longing and nostalgia for the past. Their alienation was one of the major characteristics of their poetic reference. Because of the hard circumstances they experienced in America as exiles and immigrants, they composed the best poems showing their feeling of homesickness. Hamzah (2016) stresses that "exile is the antithesis of homeland and invites the use of motifs derived from the conflict between separation from one's homeland and soil and the desire to return. Among these motifs are memory, nostalgia, return and absence.” (P.256) America was a rich place for the immigrants to write about their longing to homelands because it was a source of inspiration, so they composed great poems with free rhythm and verses. Khafaji (1986) adds that immigrants' feelings and sadness towards their people and homelands were highlighted in their poems.

\section{REFERENCES}

[1] Al-Issa, F.A. (2003). Living on the Hyphen: The Literature of the Early Arab- American between 1870-1940, Electronic Theory, Treatises, and Dissertation, Florida State University Libraries.

[2] Diab, N., M. (2015). Inter- religious Tolerance: Ameen Rihani's key to Religious Reform and political unity, Journal of Intercultural Inquiry, vol. 1, No.1:43-59.

[3] Ghareeb, A. (1988) Riddles, in G Orfalea and S. Elmusa (ed.) Grape leaves: A Century of Arab American poetry, Salt Lake City: University of Utah press.

[4] Hamzah, H. (2016) exile in contemporary Palestinian poetry, International Journey of Language and Literature, Vol. 4, No.1, 256-268.

[5] Jokandan, M.S. and Mahmoud Shakib. (2015). Reviewing Social Values in Mahjar Literture, International Journal of Current Life Sciences, Vol.5, Issue 3:427-431).

[6] Karam, S. (2013) “Ameen Rihani’s Visionary Support for women a century Age” International Journal of Social Sciences and Humanities, vol.3, No.5: 488-493.

[7] Khafaji, M.A. (1986). Qesal al-abad al-Mahjary, Beirut: Dar Al-Kottab al-lobnany.

[8] MecHark, S. (2006). Khalil Gibran and other Arab American Prophets, Unpublished M.A thesis, The Florida State University.

[9] Moreh, S. (1976) Modern Arabic poetry 1800-1970: The Development of its Forms and Themes Under the Influence of Western Literature, Leiden: E.J.Brill.

[10] Orfalea, G. and Sharif, E. (1988). Grape Leaves: A century of Arab American poetry, Salt Lake City: University of Utah Press.

[11] Perry, J. R. (1988). Close your Eyes and see, in G. Orfalea and S. ALmusa (ed.), Grape Leaves: A century of Arab American poetry, Salt Lake City: University of Utah press.

[12] Said, E. W. (2000). Reflection on Exile and other Essays, New York: E.W.S.

[13] Said, E. W. (2003). Orientalism, London: Penguin. 


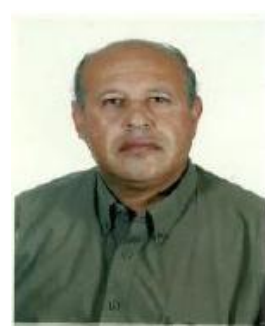

Ibrahim Mohammad Abushihab was born in Jordan 1958. He got his BA in English and MA in TEFL from Yarmouk University/Jordan (1986), whereas PhD degree in Applied Linguistics was received from Gazi University/Turkey (2003). Over the past 30 years he has been teaching English as a foreign language to Arab students in the Ministry of Education in Jordan, Aljouf University (Saudi Arabia) and Alzaytoonah Private University of Jordan. Since then, he has been doing research in the field of Linguistics, Discourse Analysis, Stylistics, Applied Linguistics and Contrastive Analysis. Dr. Ibrahim Abushihab is a Professor of Applied Linguistics at Alzaytoonah University of Jordan.

Enas Sami Awad got her BA in English/Translation from Al-Esraa University of Jordan, whereas MA degree in translation was received from Petra University of Jordan.

Esraa Ibrahim Abushihab got her BA and MA in English/Literature from Yarmouk University of Jordan. 